\section{Beyond the language barrier}

SIR - A recent note in Nature ${ }^{1}$ tells of the Japanese chemist Eiji Osawa who was devastated when he first saw the original 1985 paper describing the discovery of buckminsterfullerene. In 1970, while at Kyoto University, Osawa had predicted the possible existence of a $\mathrm{C}_{60}$ molecule with a geodesic structure, which he published in Japanese. Fifteen years later his work was unknown to the group that subsequently received the Nobel prize ${ }^{2}$.

Ignorance of published work within various fields is still a major problem. Abstracting and indexing services continue to improve and provide information on the latest works published, but the proliferation of international and regional journals makes it difficult to keep up with the literature. It is understandable that many English-speaking scientists fail to read journals in foreign languages, such as Japanese, without translations. But ignorance of important articles in local foreign journals published in English is also increasing.

The Japanese have made an active effort to publish society and local journals in English. Within the field of neuroscience, journals such as Neuroscience Research (from the Japan Neuroscience Society) and Journal of Brain Science (Japan Brain Science Society) are examples of important English-language journals based in Japan. And many of the 80 Japanese medical schools publish their own English-language journals. With an increasing number of countries with important research enterprises, it is clearly difficult to keep up with discoveries by international scientists unless they are published in international journals. But there are many reasons why a scientist may want to publish important work in a particular local or regional journal.

Access to scientific information is important. While it could be argued that scientists should try to publish their most important work in leading international journals, that is unfair. The burden is on each of us to find innovative ways to keep in touch with the ever-expanding scientific literature. Abstracting, indexing and Internet services should continue extending their coverage of the world's scientific journals. If it is assumed that the international scientific language is English, then regional and local foreign institutions should continue Japan's approach of providing important English-language journals. In this way important discoveries such as the $\mathrm{C}_{60}$ carbon atom, as originally described by Osawa, will not be rediscovered 15 years later because of a language barrier.

\section{Paul R. Sanberg}

Cesario V. Borlongan

\section{Hitoo Nishino}

Division of Neurological Surgery,

University of South Florida

College of Medicine,

12901 Bruce B. Downs Blvd,

Tampa, Florida 33612, USA

and

Department of Physiology,

Nagoya City University Medical School, Mizuho-ku,

Nagoya 467, Japan

1. Swinbanks, D. Nature 383, 562 (1996).

2. Kroto, H. W., Heath, J. R., O'Brien, S. C., Curl, R. F. \& Smalley, R. E. Nature 318 167-163 (1985).

\section{Closure explained}

SIR - I was disappointed to read your recent News article "Closure of astrophysics laboratory blamed on Enola Gay 'fallout'" (Nature 383, 367; 1996). The author's suggestion that closure of the Laboratory for Astrophysics is some form of "retribution" against a former museum director are supported with a single quotation from one anonymous "colleague" of a staff member. Allow me to set the record straight.

The Laboratory for Astrophysics is being closed because current fiscal realities dictate that the National Air and Space Museum must concentrate on its core function, the care of the national collection. A report in October 1995 by the General Accounting Office describes in great detail the critical needs of the air and space collection. Similarly, the September 1995 management review by the National Academy of Public Administration concludes that the "research activities pursued by the astrophysics laboratory are not a crucial element of the museum".

Although the primary funding for the laboratory came from grants, two of the three employees' salaries came from federal funds. Closing the laboratory is one of many difficult decisions that the museum's management has had to make to ensure that the museum continues to meet its primary responsibility, stewardship of an unparalleled collection of unique artefacts from aviation and space exploration history. To suggest any other motivation does a disservice to the entire staff of the museum.

\section{Donald S. Lopez}

National Air and Space Museum, Smithsonian Institution, Washington, DC 20560, USA

\section{Genome patents}

SIR - Any effort to illuminate the debate on the ownership of the human genome by an objective quantified analysis is laudable. But failing to take into account the pace at which techniques and methods evolve can greatly limit the scope of the results. The recent analysis by members of the Science Policy Research Unit (SPRU) at the University of Sussex in England (Nature 380, 387-388; 1996) focused on human DNA sequence patents granted before 1995, and so covered work carried out mainly with classical techniques. We have adopted an alternative approach, surveying filed (and not only granted) patents for human and non-human sequences, as well as methods of genome analysis.

Our results draw on two databases: the Science Citation Index for scientific research at the international level $(50,903$ bibliographic references for 1991-95) and the
Derwent Biotechnology Abstracts for patents (6,105 patents for the same period - five times more than the SPRU database).

Like the SPRU team, we found that Europe was lacking in capacity to transfer basic research to industrial applications. Europe accounts for $39 \%$ of all scientific publications on genomic research but is responsible for only $21 \%$ of all patents. This weakness, which is not limited to genomic research, will require specific measures if Europe is to remain competitive.

The main difference between our results and those of the SPRU team lies in the private sector. Analysing the most involved organizations, we found that the proportion of Japanese companies filing patents (37\%) is roughly the same as that of US companies $(35 \%)$, whereas the SPRU team found that Japanese companies owned $50 \%$ of patents and that US companies owned $25 \%$. And although public-sector research is marginal in the SPRU analysis, with public institutions owning $17 \%$ of patents granted world- wide, it is central in our results, accounting for $38 \%$ of all patents filed (United States $54 \%$, Europe $43 \%$, Japan $0 \%$ ).

Overall, this puts the United States in the lead $(47 \%)$ with Japan $(26.6 \%)$ a serious competitor to Europe (21\%). Which results should be recognized? It depends on whether one wants to identify the current owners of genes or the players developing the competence and tools that give them a good chance of owning such patents tomorrow. Bearing in mind that only 1 per cent of all genes are today protected by patents, an analysis based on the identification of potential and not only of acquisition has clear advantages.

P. B. Joly

M. A. de Looze

V. Mangematin

INRA/SERD,

R. Coronini

IREPD,

Université Pierre Mendes-France,

BP47, 38040 Grenoble Cedex 09, France 